\title{
Public Administration in Albania and the Process of European Integration
}

\author{
Glori Husi \\ Phd Candidate, Law Faculties Of University Of Tirana And Albanian University \\ EMail: glorihusi@gmail.com
}

\section{Doi:10.5901/ajis.2015.v4n2s2p300}

\section{Abstract}

A stable, efficient and accountable public administration, in Albania, is a sine qua non for the proper functioning of the institutions, observance of the rule of law, protection of individual rights of the Albanian citizens, while serving their interests at the highest possible degree and paving the road for ever closer relations between the European Union and Albania and the latter ultimate successful membership. For more than two decades, Albania has striven unsuccessfully to build a proficient public administration. Short term political gains and corruption have kept public administration rather weak, with limited administrative capacity, high levels of politicisation and a lack of transparency, unable to promptly and timely serve citizens' needs. The last attempt to consensually adopt a firm legal framework of substantial guarantees for civil servants was succumbed in the last minute to political intervention aimed at accommodating activists' demands for employment. If Albania is to consolidate an unbiased and professional public administration, its political establishment must make a real commitment to refrain from political interference and to fully implement a truly consensual and all-inclusive legal and institutional reform with genuine guarantees for a transparent, merit and efficacy based system of recruitment, career and performance of civil service. Changes in the system of elections, improvement of business climate, as well as enlargement of market freedoms and individual opportunities definitely help lowering the pressure for a secure and unmerited job in the public service.

Keywords: public administration, politicization, reform, proficient.

\section{In place of an introduction}

In June 2006, Albania signed a Stabilisation and Association Agreement (SAA) ${ }^{1}$ with the European Communities (today the European Union) ${ }^{2}$ and their Member States, which entered into force on 1 April 2009. On the preamble to this Agreement, the parties express their commitment to contribute by all means to the political, economic and institutional stabilization in Albania, through the development of civil society and democratization, institution building and public administration reform ${ }^{3}$, as well as their commitment to respect human rights and the rule of law ${ }^{4}$.

Title VIII of the SAA regulates cooperation policies between the parties. With regard to public administration, it has been agreed upon that cooperation shall aim at ensuring the development of an efficient and accountable public administration in Albania, able to support rule of law implementation, the proper functioning of the institutions for the benefit of the Albanian citizens, first and foremost, as well as the smooth development of the relations between the European Union and Albania 5 . It is further understood that cooperation in this area shall focus, inter alia, on institution building, the development and implementation of transparent and impartial recruitment procedures, human resources management, career development for the public service, continued training and the promotion of ethics within the public administration ${ }^{6}$. The SAA is one of the three pillars of the so-called Stabilization and Association process (SAP) that was

\footnotetext{
1 See Stabilisation and Association Agreement between the European Communities and their Member States, of the one part, and the Republic of Albania, of the other part (SAA), [2009] OJ L 107/166.

2 The European Union has replaced and succeeded the European Community. See to that effect Article 1, paragraph 3, last sentence of the Treaty on European Union (Consolidated version), [2012] OJ C 326/13.

${ }^{3}$ See the third recital on the Preamble.

4 See the fourth recital on the Preamble.

${ }^{5}$ See Article 111 of the SAA.

6 Ibidem.
} 
firstly launched in June 19997, but it really jumped off after the Thessaloniki Summit of June $2003^{8}$. The other two pillars include the financial assistance of the EU towards the countries of the Western Balkans (WB), mainly through the Instrument for Pre-accession Assistance (IPA), and, last but not least, the establishment of regional cooperation and good neighborly relations. In order to assess compliance by these countries with the conditionality of the Stabilisation and Association process, since March 2002, the Commission has prepared regular and periodic reports for the Council and the European Parliament ${ }^{9}$.

Especially since 2009, the European Commission has increased its emphasis on public administration reform in Albania and the countries of the Western Balkans, and considers it to be amongst the first priorities of the enlargement strategy together with the rule of law and economic governance ${ }^{10}$. The reason is clear, while these countries are moving closer to the EU, public administration "remains weak ..., with limited administrative capacity, high levels of politicisation and a lack of transparency"11. This and the permanent turnover of staff due to political considerations has been, more or less, a consistent finding of the European Commission in all its progress reports and other assessment documents ${ }^{12}$. It is, indeed, an unacceptable inconsistency taking into account the strong aspirations of their peoples to become as soon as possible part of the European family of western values guaranteed by modern and efficient states that enforce the rule of law and protects individual rights. Since 2014, the Commission has decided to change strategy and move to a "a more structured dialogue" by "setting up 'special groups"'13 on public administration reform with the enlargement countries.

The aim of this paper is to examine the state of public administration reform in Albania against the backdrop of the integration process. The center of attention will focus on the causes of the problem, as well as the main challenges and obstacles lying ahead. The paper will conclude with a number of recommendations regarding appropriate solutions for reforming public administration and building an efficient system of civil service that will withstand the test of time.

\footnotetext{
7 See Commission Communication to the Council and European Parliament on the stabilisation and association process for countries of South-Eastern Europe, 26.05.1999, COM(1999)235 final (8858/99). See also Conclusions of the Presidency of the Cologne European Council, held on 3 and 4 June 1999.

${ }^{8}$ See European Council Declaration, Eu-Western Balkans Summit, Thessaloniki, 21 June 2003, 10229/03 (Presse 163) OJ 2003, C/03/163, point 8; and Conclusions of the Council of General Affairs and External Relations on the Western Balkans, The Thessaloniki agenda for the Western Balkans: Moving towards European integration, Luxembourg, 16 June 2003, 10369/03 (Presse 166), C/03/166, Annex A. See also Conclusions of the Presidency of the European Council, Santa Maria da Feira, 19-20 June 2000, part VD, point 67; Conclusions of the Presidency of the European Council, Copenhagen, 12-13 December 2002, point 23.

9 For more information, consult the official website of the Delegation of the European Union to Albania, at: http://eeas.europa.eu/delegations/albania/eu_albania/progress_reports/index_en.htm .

10 See European Commission, Communication from the Commission to the European Parliament, the Council, the European Economic and Social Committee and the Committee of the Regions: Enlargement Strategy and Main Challenges 2014-15 \{SWD(2014) 301 to 307 final\}, Brussels, 8.10.2014, COM(2014) 700 final, p. 1, first paragraph.

11 Ibid., p. 2.

12 See for instance: Commission of the European Communities, Report from the Commission - The Stabilisation and Association process for South East Europe - First Annual Report \{[SEC(2002) 339] [SEC(2002) 340] [SEC(2002) 341] [SEC(2002) 342] [SEC(2002) 343]\}, Brussels, 03.04.2002, COM/2002/0163 final, ANNEX A, [SEC(2002) 339], p. 15; Commission of the European Communities, Staff Working Paper: Albania Stabilisation and Association Report 2003 \{COM(2003) 139 final\}, Brussels, 26.3.2003, SEC(2003) 339, p. 2; Commission of the European Communities, Staff Working Paper: Albania Stabilisation and Association Report 2004 \{COM(2004) 203 final\}, Brussels, SEC(2004) 374 /2; p. 3, 4; Commission of the European Communities, Staff Working Paper: Albania Stabilisation and Association Report 2005 \{COM (2005) 561 final\}, Brussels, 9 November 2005, SEC (2005) 1421, p. 11, 12 et seq.; Commission of the European Communities, Staff Working Paper: Albania Stabilisation and Association Report 2006 \{COM (2006) 649 final\}, Brussels, 8.11.2006, SEC (2006) 1383, p. 7; Commission of the European Communities, Staff Working Document: Albania Stabilisation and Association Progress Report 2007 \{COM (2007) 663\}, Brussels, 6.11.2007, SEC (2007) 1429, p. 8; Commission of the European Communities, Staff Working Document: Albania Stabilisation and Association Progress Report 2008 \{COM (2008) 674\}, Brussels, 5.11.2008, SEC(2008) 2692, p. 8; Commission of the European Communities, Staff Working Document: Albania Stabilisation and Association Progress Report 2009 \{COM (2009) 533\}, Brussels, 14.10.2009, SEC(2009) 1337/3, p. 9.; European Commission, Communication from the Commission to the European Parliament and the Council: Enlargement Strategy and Main Challenges 20122013 \{SWD(2012) 331 to 337 final\}, Brussels, 10.10.2012, COM(2012) 600 final, p. 51; European Commission, Report from the Commission to the Council and the European Parliament: on Albania's Progress in the Fight Against Corruption and Organised Crime and in the Judicial Reform, Brussels, 4.6.2014, COM(2014) 331 final, p.1; European Commission, Staff Working Document: Albania Stabilisation and Association Progress Report 2014 \{COM(2014) 700 final\}, Brussels, 8.10.2014, SWD(2014) 304 final, p. 9;

${ }^{13}$ Enlargement Strategy and Main Challenges 2014-15, p. 3.
} 


\section{Where lies the problem?}

Albania has not inherited a solid tradition in the field of public administration. The beginning of the 1990's and the establishment of pluralism found Albania a country striving to build democracy and develop a market economy, in a rapidly changing political environment, with unstable institutions, no tradition of the rule of law, whatsoever, and a massive unemployed labor force that, when unable to leave the country for a better life elsewhere, would do anything to get a "secure job" in the public sector. Even though the public sector was shrinking rapidly and public administration jobs paid lousy wages, they were still more attractive than the insecurity of the future, ahead. Unemployment was particularly high at that time due to the process of speedy transformation into a market economy. Albeit a lack of accurate statistics, the unemployment rate in 1992 was estimated at least over 30 percent ${ }^{14}$. High unemployment rates continued with moderate decreases until 1996 and jumped to extreme during the turmoil of 1997 and the years following that. The last ten years, the unemployment rate has decreases, but it is still much higher than the European average. During the period 2000 to 2013, registered unemployment rate saw a constant reduction (with small oscillations) from 16.8 in 2000 to 13 percent in the year 2012. In 2013, unemployment rate for all citizens 15 years old and above jumped again to 16.8 percent, whereas in 2014, unemployment reached a record high of 18 percent ${ }^{15}$.

In fact, the entire period of transition from a centralized to a market economy has been characterized by high levels of unemployment. This exerts tremendous amount of pressure on the latter, which base their electoral campaign not on general pledges that once in government they are going to boost employment but also on direct promises to their militants and voters that they will hire them and their family members in public positions in exchange for their votes. Hence, the findings of the EU Commission that there is a "politically motivated staff turnover"16 and that "public service remains overly politicised."17

Moreover, Albania has struggle hard to fight poverty and emerge from an underdeveloped into a developing country. Still, even after 24 years of pluralism and a liberalized economy, Albania continues to fight poverty. In 2015, for instance, GNI per capita was estimated at 4700 US dollars ${ }^{18}$, while the respective figure for the Euro Area is 39,601 US dollars ${ }^{19}$, and Albania ranked $125^{\text {th }}$ country in the world20. On Human Development Index, Albania ranked $95^{\text {th }}$ in the world in $2014^{21}$. Without any doubt, poverty and uncertainties of transition make public jobs a very attractive commodity.

In addition, peculiarities of the elections system in Albania exacerbate this pressure. In the last general elections of 2013, for example, there were over 5508 voting centers composed of at least 7 members, which makes in total some 39 000 people appointed by the parties to observe the voting process and safeguard its reliability. In addition, there were 89 Ballot Counting Centers comprised of at least 2880 counters, divided into counting groups of four, and some 2880 replacement counters, in total some 5800 people ${ }^{22}$. To these numbers, one could add a couple of thousand more charged with the duty of party observers and distributed in all voting and counting centres. Given the continuous and unrelenting distrust ${ }^{23}$ that Albanian political parties have shown towards each others during these last 24 years of

\footnotetext{
14 See for instance Albania Business Law Handbook, $5^{\text {th }}$ Edition, International Business Publications, USA 2008, p. 48. However this is a moderate figure if one takes into consideration that most of idle workers were paid $80 \%$ of the wage throughout 1991, but were not considered unemployed for statistical purposes.

${ }^{15}$ Data are taken from the official publications of Albanian Institute of Statistics, INSAT. All data pertaining to the labor market and unemployment in Albania can be accessed online, at: http://www.instat.gov.al/al/themes/tregu-i-pun\%C3\%ABs.aspx?tab=tabs-5 .

16 See European Commission, Commission Staff Working Document: Analytical Report \{COM (2010) 680\}, Brussels, 09.11.2010, SEC(2010) 1335, p. 15.

17 Enlargement Strategy and Main Challenges 2014-15, p. 20, point 13.

${ }_{18}$ Measured based on the Atlas method. See The International Bank for Reconstruction and Development / The World Bank, Doing Business 2014, Economy Profile: Albania, page 6.

${ }_{19}$ Measured based on the Atlas method. See for more World Development Indicators database, World Bank: Gross national income per capita 2013, Atlas method and PPP, at: http://databank.worldbank.org/data/download/GNIPC.pdf .

20 Ibid. The survey data include 213 countries in total. Average Worldwide GNI per capita is estimated at 10679 US dollars.

21 In total, 187 countries were included into the survey. See United Nations Development Programme, Human Development Reports, 2014 Human Development Statistical Tables, at: http://hdr.undp.org/en/data .

22 Source: Albanian Central Elections Commission. Website: http://www2.cec.org.al/sq-al/. The law foresees that "there are two Counting Teams for each counting table", see Article 95/1, second sentence of the "Electoral Code of the Republic of Albania", (Approved by Law No. 10 019, of 29 December 2008, and amended by Law No. 74/2012, of 19 July 2012).

23 This is also a major inherent problem of Albanian politics clearly indicated in all OSCE report. For illustration, see Office for Democratic Institutions and Human Rights, Republic of Albania Parliamentary Elections 23 June 2013: OSCE/ODIHR Election Observation Mission Final Report, Warsaw, 10 October 2013, p. 1, second paragraph.
} 
democracy, above all, before and during the process of elections, this army of "elections functionaries" gains a very significant and indispensible role in the election encounter. They are carefully screened and selected among hardcore militants without regard to any special skill or education, as long as they fulfil a non negotiable criterion, i.e., unquestionable loyalty to their parties, and, by all, means safeguard their votes. In return, parties remain indebted to these militants, which usually ask nothing else than a secure job in public administration when their respective parties win the elections.

It can be easy deduced from the aforementioned that the country is caught in a vicious circle: parties totally distrust each-other and need loyal militants to protect their votes. These militants ask nothing in return but a position in public administration. But when political parties win elections and are positioned at the helm of the government, they must also deliver on EU criteria, including the consolidation of an efficient public administration. This, brings them before a major dilemma, either keep a high professional level of public administration and alienate militants, or hire militants, despite their professional shortcomings, and try to train them in hope that they will gain the requisite level of proficiency. Again, the last option does not stand a great chance because with the next rotation of power, trained or untrained militants rotate too, and parties that form the new government start building their "own" public administration anew.

One more crucial factor tempting party supporters to exert pressure and ask positions in public administration is the fact that, as in many other countries in transition, a public administration position may offer unique opportunities to prosper fast. In 2014, Albania was ranked $110^{\text {th }}$, out or 175 countries, with a score of thirty three (out of 100) in the corruption index of Transparency International ${ }^{24}$. This is not a novelty. All reports of the European Commission identify corruption as one of the most difficult obstacles for Albania on her road ahead. In a country with a weak rule of law, where government interference remains high and frequent, where laws, regulations and paradigms change abruptly ${ }^{25}$ and where there is no regard for legal certainty, having administrative powers and discretion is tantamount to a very profitable business. Humans, being rational beings, tend to continuously calculate their odds for any move they do, putting into balance arguments in favor of and against a particular action. In the case of public officials in Albania, these arguments go as follows: work honestly in the public service for little money and an uncertain period of time, at the end of which a new struggle for survival will begin afresh, or plunge into bribery and prosper since the probability of repercussions by the rule of law or the government you helped come to power are almost inexistent. It easy to guess which choice a pragmatic human being would choose. The formulation of US Department of State is quite telling in this regard: "The most significant human rights problems were: pervasive corruption in all branches of government, and particularly within the judicial system"26. Under these conditions, logically, public administration positions remain highly sought after in Albania, and naturally, this increases the pressure on political parties for staff turnover.

Regrettably, all the aforesaid factors have a direct effect on the inefficiency of public administration. But most worrisome is the fact that the uncertainty of employment in conjunction with possibilities for financial gains and a weak rule of law make the entire system more prone to corruption. And this is only a part of the problem. Bureaucracy, lack of responsibility and concentration of decision making is present at every level of Albanian administration which is notorious for long waiting lines at the counters and the fact that in every institution there is only one person who has the right to sign official document and no one get to be served if the director is missing.

\section{Legal regime of public employment in Albania}

Albanian Constitution ${ }^{27}$ provides for the establishment, organization and functioning of state institutions. Albanian Constitution states that "guarantees of tenure and legal treatment of public employees are regulated by law"28. There is no unified system on the general organization and functioning of the public administration of all state institutions,

\footnotetext{
24 Consult the report, at: http://www.transparency.org/country\#ALB .

25 For example, Law No. 8405, of 17 September 1998 has been amended 12 times in the last 10 years, by the following Laws: No. 10319, of 16.09.2010; No. 10137, of 11.05.2009; No. 10097, of 19.03.2009; No. 10078, of 16.02.2009; No. 9843, of 17.12.2007; No. 9743, of 28.05.2007; No. 9632, of 30.10.2006; Normative Act of the Council of Ministers No. 4, of 13.12.2005; No. 8991, of 23.01.2003; No. 8682, of 07.11.2000; No. 8453, of 04.02.1999; and Constitutional Court of Albania, Decision No. 2, of 25.01.1999, Official Journal No. 2, p. 11.

${ }^{26}$ See Albania 2013 Human Rights Report, Country Reports on Human Rights Practices for 2013: United States Department of State, Bureau of Democracy, Human Rights and Labor, p. 1, paragraph 2.

27 See Law No. 8417, of 21.10.1998 "Constitution of the Republic of Albania", decreed by Presidential Decree No. 2260, Official Journal No. 28, of 21 October 1998, page 1073, as amended by Law No. 9675, of 13.1.2007, Official Journal No. 2, of 14 January 2007, page 39 and by Law No. 9904, of 21.4.2008, Official Journal No. 61, of 7 May 2008, page 2728.

28 See Article $107 / 3$ of the Constitution of the Republic of Albania.
} 
although, a major step forward was made with the approval of Law no. 90/2012, "On the organization and functioning of the state administration"29, albeit its limitations in scope. Article 1 of this Law 90/2012 defines its purpose and scope as "to create a legal framework for the organization and functioning of State Administration under the responsibility of the Council of Ministers". Nevertheless, institutions of public higher education, Albanian embassies abroad, as well as the Armed Forces are not included in the scope of this law (see Article 1 point 2). Also, the administration services of independent institutions and courts do not fall within its ambit.

With regard to recruitment, employment conditions, disciplinary measures, promotions, transfer and eventual dismissals of employees working in the public sector, two distinctive legal regimes have emerged: first, the consecutive legal frameworks on Civil Servants, which regulate the relationship between the state and civil servants and determine the rules on organization and functioning of the service for all institutions that fall within their ambits ${ }^{30}$, and second, the Labor Code ${ }^{31}$, which regulates employment relationships between employers and employees in all other public institutions that have not been included within the scope of civil service legislations. Employment relationships in the private sector are exclusively regulated by the Labor Code. It is important at this point to briefly discuss the historic development of Albanian legislation on labor relationships since the establishment of pluralism in order to gain a better understanding of the current legal situation.

The first law to regulate labor relations in Albania after the fall of the totalitarian state was Law 7526 of 3 December 1991 "On labor relationships"32. This amended the Labor Code of $1981^{33}$, an ideological effort of the communist regime to legally formalize whatever was left from the feeble labor relations between enslaved workers and a totalitarian regime. Article 4 of Law 7526 stipulates that labor relationships are established on the basis of an agreement between employer and employee. This law attempted to regulate in 36 articles issues linked to the validity and the rights of parties from the agreement, disciplinary measures, and the eventual termination of the agreement. The law did not distinguish between employment in private sector and that in public sector and did not clarify whether or not state institutions, being public legal persons, fall within the scope of the subjects of the law as employers ${ }^{34}$.

In 1995, Albanian Parliament approved Law nr. 7961, "The Labor Code"35. This new Labor Code - a significant step forward in the field of labor relationships in Albania - has abrogated the old Labor Code of 1981, the Law 7526 of 1991 "On labor relationships" and all other relevant legislation in this domain, and regulates in a cohesive and comprehensive way all aspects of employer-employee relationships. Article 4 of the Labor Code defines negatively the group of subjects falling within the scope of the law by setting a general rule that safe for cases when particular employment relationships are regulated by means of a special law or sector specific law, all other employment relationships fall within the scope of this Code. Moreover, the Code is applicable even for persons whose employment is regulated by a special law, when the latter does not foresee solutions for particular problems connected with employment relationships (Article 4).

The legal relationship of employment, regulated by the Labor Code is in fact a contractual relationship of the kind dealt with by the Civil Code, under the part "obligations", in Albania and other countries of Civil Law tradition, or by the law of contracts in countries of common law legal systems ${ }^{36}$. The most fundamental pillar of this relationship is the employment contract, which, in fact, comes down to concurrence of wills between the parties that they are entering a relationship of mutual legal obligations, i.e., the employee to offer labor or services for a fixed or unfixed period of time and under the guidance, management and orders of employer, who undertakes to pay a given remuneration ${ }^{37}$. The employment contract need not be a written one or of a particular type. As a result, this is a relationship between parties and, unless otherwise provided for in the law, parties can enter freely into employment relationship and reserve the right

29 See Law No. 90/2012 "On the organization and functioning of the state administration", Official Journal No. 135, of 17 October 2012, p. 7695.

30 The latest framework law on this regard is Law No. 152/2013 "On Civil Servant". See Article 1 thereof.

31 See Law No. 7961, of 12 July 1995 "Code of Labor of the Republic of Albania", and its subsequent amendments Law No. 8085, of 13.3.1996, Law No. 9125, of 29.7.2003 and Law No. 10 053, of 29.12.2008.

32 See Law No. 7526, of 3 December 1991 "On labor relationships", Official Journal No. 9, of 27 December 1991, page 412.

33 See Law No. 6200, of 27.6.1981 "Code of Labor of the Socialist People's Republic of Albania".

${ }_{34}$ For more on the historical development of labor see Kudret Çela, E Drejtë e Punës, Shtëpia Botuese "llar" 2005, p. 27 et seq.

35 See Law No. 7961, of 12.07.1995 "Code of Labor of the Republic of Albania", as amended by Law No. 8085, of 13.3.1996, Law No. 9125, of 29.7.2003 and Law No. 10 053, of 29.12.2008.

${ }^{36}$ See for more Kudret Çela, E Drejtë e Punës, p. 113-143.

${ }^{37}$ See Article 12 of the Code of Labor. 
to terminate it, at any time, with mild consequences consisting mainly of financial compensation for the damage occurred. A right entitling existing employees or unjustifiably dismissed employees to hold and/or return to their job positions, whether in public administration or private sector, is not recognized ${ }^{38}$.

Until the time of adoption of the Labor Code in 1995, pluralistic Albania has had no particular legislation establishing a special legal regime for public servants. But things were about to change. Some nine months later, the Parliament adopted Law 8095 of 21 March 1996, "on the Civil Service in the Republic of Albania"39, the first piece of legislation providing for a special regime for civil service in the public sector. The object of this law was to regulate "legal relationships of employment of employees of central and local public administration and other budgetary institutions that are not regulated by special laws or the Labor Code" (Article 1). Its aim was to regulate "legal relationships in the civil service aimed at guaranteeing the rights and suitable conditions for public administration employees in order to better fulfill ... the duties of public administration, ..., ensure continuity in activities of public administration, sanction the rights and obligations of employees, and to establish unique rules for commencement and termination of their legal relationship, career development, conditions and criteria for their recruitment' (Article 4).

There was some confusion, however, with regard to the notion of civil service since in addition to public servants charged with duties of supervisory, organizational, control and executive nature, the law defines it to include political functionaries, whose legal position was regulated by other specific laws, as well as ordinary employees that offer particular services within public administration (see Article 2). Subsequent legislations on civil service addressed this by making a clear differentiation between pure civil servants and other officials and/or "administrative employee" 40 . Law 8095 foresaw that civil servants were to be recruited after a concurring procedure or appointed directly (without concur) by the supervising authority (Article 19) and the employment relationship, in principle, would last for an indefinite period of time (Article 18). It also prescribed several guarantees with reference to career advancement, training, and political rights of civil servants, and foresaw a detailed procedure for disciplinary measures. Article 33 point 1 states, inter alia, that "The civil servant has also the following special rights: 1 . The right to have a guaranteed job in the civil service, until retirement, in accordance with the conditions and requirements of this law."

In 1999, a new piece of legislation on civil service, namely Law No. 8549, "On the Status of the Civil Servant"41, was adopted by Albanian Parliament. This law repealed the previous Law no. 8095 of 1996 and set forth important improvements and clarifications. It aimed at laying down conditions and procedures for entering the public service, the mode of establishment and termination of the work relations, career advancement, to guarantee the rights and define the duties of civil servants aimed to create a professional, stable and efficient civil service (Article 1, point 1). It established the Department of Public Administration (DAP) as the main body charged with the administration of the civil service, as well as the Civil Service Commission, as an independent institution charged with supervisory responsibility.

This law included a general presumption of applicability of the Labor Code in all matters not expressly regulated by it (Article 1, point 3). It clarified the notion of civil servants by defining in Article 2, point 1, that civil servants are those employees of institutions of central or local public administration who exercise public authority in functions of a managerial, organizational, supervisory or implementing nature. And then again, it went on producing confusion when, on the one hand, it defined institutions of central or local public administration are considered the Parliamentary Administration, the Presidential Administration, administration of the Council of Ministers, the Ministries, independent central institutions, municipalities and regions (Article 2, point 2), and, on the other, it introduced a differentiation between institutions of the central administration, which referred to the administration of the Council of Ministers and the Ministries (Article 2, point 3) and "independent institutions" which referred to the independent central institutions, the Parliamentary Administration, the Presidential Administration, municipalities and regions (Article 2, point 4). This confusion was aggravated further when the law foresaw in Article 2 point 6 that "the institutions of central or local public administration which are governed by special law shall be subject to the provisions of this law, except when the provisions of the special law differ from this law"?!

Articles 9 and 10 also did not help in this regard with the provision of "individualized" civil services adjusted to the "nature" of the institution. Thus, the "Institutions of Central Administration shall be responsible for the administration of their subordinated civil service" (Article 9, first sentence) and "submit to the Department of Public Administration requests

\footnotetext{
38 See for instance Supreme Court of Albania, Unifying Decision No. 7, of 01.06.2011.

39 Law No. 8095, of 21.3.1996 "On Civil Service of the Republic of Albania", as amended by Law No. 8300, of 2 March 1998.

40 See for instance Law No. 152/2013, of 30.5.2013 "On Civil Servants", Article 4.

${ }^{41}$ See Law No. 8549, of 11.11.1999 "On the Status of the Civil Servant" and its consecutive amendments.
} 
for the filling of vacant positions and for promotions" (Article 9/A), whereas "independent institutions are responsible for managing their own civil service ... [and] shall create their own departments of personnel to manage their civil service" (Article 10/1), but "fill their vacant positions by means of internal transfers of a temporary nature" and "nominate the ad hoc committees for recruitment, promotions and lateral transfers" without going through the institution in charge of the civil service observance, DAP (Article 10/1, a \& e). DAP maintained in its subsequent practice that only public employees of central administration institutions, i.e., the Council of Ministers and Ministries, on the whole, some 5,000 civil servants benefited fully from the guarantees of the Status of the Civil Servant.

These guarantees included, inter alia, recruitment by means of open competition based on merit (Article 13), roster preference of actual civil servants in cases of new vacancies (Article 15 point 1), lateral transfer (Article 15 point 2 and Article 20) and promotion (Article 15 point 4 and Article 20), a guaranteed position in the public administration (Article 20), strict disciplinary procedures (Article 25) and a limited number of circumstances that could lead to disciplinary measures, suspension and/or dismissal from service (Article 21 et seq.) - and all these under the close scrutiny and active involvement of DAP. Moreover, an administrative complaint could be launched with the Civil Service Commission (CSC) against any decision concerning recruitment in public service, probationary periods, promotions, lateral transfers, appraisals, disciplinary measures, and/or against any decision violating the rights of Civil Servants. CSC's decisions could be challenged before the courts of law ${ }^{42}$. This situation has changed since the entering into force of Law No. 152/2013 on civil servant and Law no. 49/2012 "On the organization and functioning of administrative courts and the adjudication of administrative disputes" and since 1 October 2013, Civil Servants could address their disputes on matters related to their employment relationship to the competent administrative court ${ }^{43}$. Regrettably, the provisions of Article 23 of Law No. 8549 in conjunction with the provisions of the Decision of the Council of Ministers No $360^{44}$ regulating the cases of closure or restructuring of institution and foreseeing the dismissal and/or dismissal of the civil servant after being transferred to a waiting list for one year period was extensively used by Albanian institution to unjustly fire public employees and replace them with party supporters.

The application of the Law No. 8549 did not achieve the establishment of an unbiased and proficient public administration; nevertheless, its implementation has led to a rich case law developed by Albanian courts, including binding decisions of the High Court and Constitutional Court, which clarifies matters pertaining to employment in the civil service and the rights of civil servants ${ }^{45}$. And then, the saga of Law No. 152/2013 "On Civil Servant" emerged. Law No. 152/2013 was consensually approved by all political parties in the Albanian Parliament on 30 May 2013 and was to enter into force on 1 October 2013. The law was supposed to bring about radical changes on the status of civil servants; in particular, with its adamant protection of their employment and other related rights. It aimed at establishing a stable and professional civil service, based on merits, moral integrity, political neutrality and accountability (Article 1 point 1). It expanded the notion of civil servant to include any official exercising public authority in a state administration institution, an independent institution, or in a local self government unit, with the exceptions of very few officials, such as elected officials, judges and prosecutors, political appointees, militaries of the armed forces, personnel of the state intelligence service, and so on (Article 2 point 1). It makes a clear distinction between civil servants and an administrative employee, the latter being an employee which carries out administrative, secretarial, maintenance, service and custodian duties and does not exercise a public authority (Article 4 point 1/d).

Law No. 152/2013 "On Civil Servant" strengthens the role of DAP (Article 7) and establishes the Albanian School of Public Administration (ASPA) charged with vocational training of civil servants (Article 8), as well as a Commissioner for Civil Service Monitoring, an administrative body responsible for monitoring the legality in the management of the civil service and having mainly supervisory powers (See Article 11 et seq.). In addition, the functions of the previous Civil Service Commission were been abolished and civil servants could file their complaints directly to the competent administrative court (Article 71). The law postulates that management of the civil service shall be governed by law and shall be based on the principles of equal chances, non-discrimination, merits, transparency, professionalism and political impartiality, and shall guarantee job stability for civil servants as well as the continuity of the civil service (Article 5). The

\footnotetext{
42 Ibid., see Article 8. Civil Servants could bring a claim against the CSC decision to the court of first instance whereas institutions could do that only before the court of appeal.

43 See Law No. 152/2013, Articles 41/3, 71/2 and 73 and Law No. 49/2012, Articles 7/c and 15/c, as well as Supreme Court of Albania, Decision No. 00-2014-730, of 6 March 2014.

44 See Decision of the Council of Ministers No. 360, of 14.7.2000 "On discharge from Civil Service".

45 See for example Supreme Court of Albania, Unifying Decision No. 7, of 01.06.2011; Supreme Court of Albania, Unifying Decision No. 8, of 12.09.2007; or Supreme Court of Albania, Unifying Decision No. 10, of 12.09.2007.
} 
civil service relationship is a relationship of administrative law. This means that decisions of public institutions that affect civil servants rights are considered administrative acts and must fulfill all the criteria thereof in order to be considered valid.

The law recognizes the rights of civil servants to appropriate working conditions and right of protection from the state (Article 33), the right to fair remuneration and salary structure (Article 34), the right to strike (Article 35), the right to join trade unions and professional associations (Article 36), the right to training (Article 38), annual paid leave and holidays (Article 40), as well as the right to participate in political activities, express political preferences publicly, or, with the exemption of TMC, be members of political parties (Article 37).

But the most significant improvement Law No. 152/2013 brought about was its rigid approach with regard to termination of civil service relationship. According to this, civil service relationship could be terminated only if the civil servant resigns, dies, loses the Albanian citizenship, retires, is convicted of a crime, or is released from duty because of unjustified refusal to accept a mandatory transfer, because of complete health incapacity, two consecutive "nonsatisfactory" performance appraisals, and/or is dismissed from the civil service, as a disciplinary sanction foreseen in Articles 57-61 of the law (Articles 63 to 66). Moreover, Law No. 152/2013 abandoned the concept of waiting list and foresaw that in cases of closure or restructuring of an institution, if the position of a civil servant ceases to exist, the latter is transferred to another position of the same category within the civil service. Therefore, Law No. 152/2013 bestowed upon civil servants unprecedented guarantees for their positions in the public administration.

This guarantee however must have not been the genuine desire of the current ruling coalition when it voted the law in Parliament back on 30 May 2013. That is why on 30 September 2013, the government hastily approved Normative Act no $5^{46}$, which postponed by six months the effects of Law No. 152/2013. The Normative Act was further endorsed by the Parliament ${ }^{47}$ in October 2013. The outcome: new rounds of public servants turnover and replacements by party affiliates. The Commission had modestly calculated that by 8 October 2014, "around $13 \%$ of staff in the central government institutions were dismissed"48. It seems that the inherent plague of public administration will not stop bedeviling Albania. The Commission emphasized data received from the Department of Public Administration, which "estimated that since September 2013, around 380 civil servants in central institutions were dismissed, resigned or put on waiting lists and around 100 were downgraded out of a total of 1392 current civil servants. The department also estimated around 5200 dismissals and resignations in subordinate institutions and agencies." ${ }^{99}$ The opposition and the Union of Dismissed Public Employees claimed this number to be much higher calculating some over 8000 public servants and employees already laid off, while the purge has only been intensified with time ${ }^{50}$

Although the Constitution Court repealed the normative act of the Council of Ministers and its endorsing law as incompatible with the Constitution ${ }^{51}$, by the time its decision entered into force on 26 February 2014, the day of its publication in the Official Journal, the damage was already done. Meanwhile, the government did not waste any time. It prepared quickly several amendments to the Law No. 152/2013 that were adopted by the Parliament on 18 December 201452, a unique Albanian story where a consensually adopted law was never able to enter into force, as approved, but was unilaterally changed immediately after the rotation of power. The new law on civil servants after the amendments brought upon by Law No 178/2014 reduces the range of public positions that were considered by Law No. 152/2013 part of civil service (Article 1), brings back the concept of waiting list (Article 25), and allows the Council of Ministers to open civil service positions of higher levels to individuals from outside the system, as well (Article 26). In a nutshell: one more

\footnotetext{
${ }^{46}$ See Normative Act of the Council of Ministers No. 5, of 30 September 2013 "On some modifications to the law no.152/2013 'On the civil servant"', Official Journal No. 159, of 30 Sptember 2013, p. 7213.

47 See Law No. 161/2013, of 17 October 2013.

48 See European Commission, Staff Working Document: Albania Stabilisation and Association Progress Report 2014 \{COM(2014) 700 final\}, Brussels, 8.10.2014, SWD(2014) 304 final, p. 9.

49 Ibidem.

50 See for instance BalkanWeb.(11.05.2015). Shoqata e të Larguarve nga Puna, letër të hapur delegacionit të BE-së: Mbroni administratën!. Retrieved from: http://www.balkanweb.com/site/shoqata-e-te-larguarve-nga-administrata-leter-te-hapur-delegacionit-tebe-se-ne-tirane-mbroni-administraten/.

51 See Constitutional Court of Albania, Decision No. 5, of 05.02.2014, Official Journal No. 18, p. 364, with object: To repeal the Normative Act of the Council of Ministers No. 5, of 30 September 2013 "On some modifications to the law no.152/2013 'On the civil servant" and the law of the Assembly No. 161/2013 "On the adoption of the Normative Act No.5, of 30 September 2013", as incompatible with Constitution.

52 See Law No. 178/2014, of 18.12.2014, Official Journal No. 211, of 14 January 2015, p. 12727.
} 
reversion to the inherent malaise.

\section{Final remarks and conclusions}

It could be safely said that, thus far, Albania has failed on her commitment to build an efficient and accountable public administration. This definitely affects liberties and the quality of life of its citizens, as well as business climate, which is already unfavorable because of incomplete recognition of property rights, weak enforcement of the law and lack of modern infrastructures. In addition, it puts into question the ability of the country to implement its commitments from the SAA and the integration process. In order to overcome this impasse, the political establishment in Albania need make a real commitment and take courageous decisions to work together truthfully and in good faith to set up and observe strict proficiency standards for building an efficient and accountable public administration. Without a true political commitment, this will not happen.

Important interventions may include changes in the system of elections so that political parties detach themselves from the quid pro quo relationships with their militants. Fast economic development and growth and a favorable business climate in conjunction with policies to eliminate corruption, bureaucracy and facilitate the start up of new and idle markets would certainly help create new and better jobs and encourage entrepreneurship. This will without doubt raise optimism and reduce the pressure for a job in the public sector. Any move to introduce and apply new and state of the art technologies in public services, any measure that will encourage outsourcing, deconcentration of responsibilities and decision making is also helpful in this regard.

However, any reform taken must be comprehensive, coherent, tangible, and directed at producing systemic changes, where lies the heart of the problem. Ad hoc and populist measures such as anonymous telephone lines for whistleblowers or open websites for public complaints bring no benefit since they educate the public to search for solutions only by pleading directly at the individual political leaders and might even lead to score-settling.

\section{Reference}

Kudret Çela, E Drejtë e Punës, Shtëpia Botuese "Ilar" 2005

\section{Legislation}

Law No. 8417, of 21.10.1998 "Constitution of the Republic of Albania", Official Journal No. 28, p. 1073

Law No. 178/2014, of 18.12.2014, Official Journal No. 211, p. 12727

Law No. 161/2013, of 17.10.2013, Official Journal No. 185, p. 7807

Law No. 152/2013, of 30.05.2013, Official Journal No. 95, p. 3952

Law No. 90/2012, of 27.09.2012, Official Journal No. 135, p. 7695

Law No. 49/2012, of 03.05.2012, Official Journal No. 52, p. 2701

Law No. 10319, of 16.09.2010, Official Journal No. 135, p. 7421

Law No. 10137, of 11.05.2009, Official Journal No. 86, p. 3775

Law No. 10097, of 19.03.2009, Official Journal No. 46, p. 2279

Law No. 10078, of 16.02.2009, Official Journal No. 22, p. 1392

Law No. 10 019, of 29.12.2008, Official Journal No. 189, p. 9305

Law No. 9843, of 17.12.2007, Official Journal No. 180, p. 5605

Law No. 9743, of 28.05.2007, Official Journal No. 74, p. 2220

Law No. 9632, of 30.10.2006, Official Journal No. 123, p. 4897

Law No. 8991, of 23.01.2003, Official Journal No. 5, p. 152

Law No. 8682, of 07.11.2000, Official Journal No. 37, p. 1808

Law No. 8453, of 04.02.1999, Official Journal No. 5, p. 151

Law No. 8549, of 11.11.1999, Official Journal No. 36, p. 1381

Law No. 8405, of 17.09.1998, Official Journal No. 23, p. 897

Law No. 8095, of 21.3.1996, Official Journal No. 13, p. 540

Law No. 7961, of 12.07.1995, Official Journal No. 16, p. 660

Law No. 7526, of 03.12.1991, Official Journal No. 9, p. 412

Law No. 6200, of 27.6.1981 "Code of Labor of the Socialist People's Republic of Albania"

Normative Act of the Council of Ministers No. 5, of 30.09.2013, Official Journal No. 159, p. 7213

Normative Act of the Council of Ministers No. 4, of 13.12.2005, Official Journal No. 94, p. 3019

Decision of the Council of Ministers No. 360, of 14.7.2000, Official Journal No. 23, p. 1202 
Treaty on European Union (Consolidated version), [2012] OJ C 326/13

Stabilisation and Association Agreement between the European Communities and their Member States, of the one part, and the Republic of Albania, of the other part (SAA), [2009] OJ L 107/166

\section{Cases}

Constitutional Court of Albania, Decision No. 5, of 05.02.2014, Official Journal No. 18, p. 364

Constitutional Court of Albania, Decision No. 2, of 25.01.1999, Official Journal No. 2, p. 11

Supreme Court of Albania, Decision No. 00-2014-730, of 06.03.2014

Supreme Court of Albania, Unifying Decision No. 7, of 01.06.2011

Supreme Court of Albania, Unifying Decision No. 8, of 12.09.2007

Supreme Court of Albania, Unifying Decision No. 10, of 12.09.2007

\section{Reports}

Commission of the European Communities, Report from the Commission - The Stabilisation and Association process for South East Europe - First Annual Report \{[SEC(2002) 339] [SEC(2002) 340] [SEC(2002) 341] [SEC(2002) 342] [SEC(2002) 343]\}, Brussels, 03.04.2002, COM/2002/0163 final, ANNEX A, [SEC(2002) 339]

Commission Communication to the Council and European Parliament on the stabilisation and association process for countries of SouthEastern Europe: Bosnia and Herzegovina, Croatia, Federal Republic of Yugoslavia, former Yugoslav Republic of Macedonia and Albania, Brussels, 26.05.1999, COM(1999)235 final (8858/99)

European Commission, Report from the Commission to the Council and the European Parliament: on Albania's Progress in the Fight Against Corruption and Organised Crime and in the Judicial Reform, Brussels, 4.6.2014, COM(2014) 331 final

Commission of the European Communities, Staff Working Paper: Albania Stabilisation and Association Report 2003 \{COM(2003) 139 final\}, Brussels, 26.3.2003, SEC(2003) 339

Commission of the European Communities, Staff Working Paper: Albania Stabilisation and Association Report 2004 \{COM(2004) 203 final\}, Brussels, SEC(2004) $374 / 2$

Commission of the European Communities, Staff Working Paper: Albania Stabilisation and Association Report 2005 \{COM (2005) 561 final\}, Brussels, 9 November 2005, SEC (2005) 1421

Commission of the European Communities, Staff Working Paper: Albania Stabilisation and Association Report 2006 \{COM (2006) 649 final\}, Brussels, 8.11.2006, SEC (2006) 1383

Commission of the European Communities, Staff Working Document: Albania Stabilisation and Association Progress Report 2007 \{COM (2007) 663\}, Brussels, 6.11.2007, SEC (2007) 1429

Commission of the European Communities, Staff Working Document: Albania Stabilisation and Association Progress Report 2008 \{COM (2008) 674\}, Brussels, 5.11.2008, SEC(2008) 2692

Commission of the European Communities, Staff Working Document: Albania Stabilisation and Association Progress Report 2009 \{COM (2009) 533\}, Brussels, 14.10.2009, SEC(2009) 1337/3

European Commission, Commission Staff Working Document: Analytical Report \{COM (2010) 680\}, Brussels, 09.11.2010, SEC(2010) 1335

European Commission, Staff Working Document: Albania Stabilisation and Association Progress Report 2014 \{COM(2014) 700 final\}, Brussels, 8.10.2014, SWD(2014) 304 final

European Commission, Communication from the Commission to the European Parliament and the Council: Enlargement Strategy and Main Challenges 2012-2013 \{SWD(2012) 331 to 337 final\}, Brussels, 10.10.2012, COM(2012) 600 final

European Commission, Communication from the Commission to the European Parliament, the Council, the European Economic and Social Committee and the Committee of the Regions: Enlargement Strategy and Main Challenges 2014-15 \{SWD(2014) 301 to 307 final\}, Brussels, 8.10.2014, COM(2014) 700 final

Conclusions of the Council of General Affairs and External Relations on the Western Balkans, The Thessaloniki agenda for the Western Balkans: Moving towards European integration, Luxembourg, 16 June 2003, 10369/03 (Presse 166), C/03/166, Annex A.

European Council Declaration, Eu-Western Balkans Summit, Thessaloniki, 21 June 2003, 10229/03 (Presse 163) OJ 2003, C/03/163

Conclusions of the Presidency of the European Council, Copenhagen, 12-13 December 2002

Conclusions of the Presidency of the European Council, Santa Maria da Feira, 19-20 June 2000

Conclusions of the Presidency of the Cologne European Council, held on 3 and 4 June 1999

Albania 2013 Human Rights Report, Country Reports on Human Rights Practices for 2013: United States Department of State, Bureau of Democracy, Human Rights and Labor

Albania Business Law Handbook, $5^{\text {th }}$ Edition, International Business Publications, USA 2008

Office for Democratic Institutions and Human Rights, Republic of Albania Parliamentary Elections 23 June 2013: OSCE/ODIHR Election Observation Mission Final Report, Warsaw, 10 October 2013

The International Bank for Reconstruction and Development / The World Bank, Doing Business 2014, Economy Profile: Albania

United Nations Development Programme, Human Development Reports, 2014 Human Development Statistical Tables 
World Development Indicators database, World Bank: Gross national income per capita 2013, Atlas method and PPP

\section{Website}

http://databank.worldbank.org/data/download/GNIPC.pdf

http://eeas.europa.eu/delegations/albania/eu_albania/progress_reports/index_en.htm

http://hdr.undp.org/en/data

http://www.balkanweb.com/site/shogata-e-te-larguarve-nga-administrata-leter-te-hapur-delegacionit-te-be-se-ne-tirane-mbroniadministraten/

http://www.instat.gov.al/al/themes/tregu-i-pun\%C3\%ABs.aspx?tab=tabs-5

http://www.transparency.org/country\#ALB

http://www2.cec.org.al/sq-al/ 